Keynote speech to the Society for Socialist Studies

2011 Congress of the Social Sciences and Humanities

\title{
AMERICAN EMPIRE, CAPITALIST CRISIS AND THE GLOBAL SOUTH
}

\author{
LEO PANITCH \\ Canada Research Chair in Comparative Political Economy \\ Distinguished Research Professor of Political Science, York University
}

\section{Keywords}

American empire; capitalist crisis; foreign direct investment; global south; underdevelopment

The vital role the Society of Socialist Studies always plays at the annual Congress of the Social Sciences and Humanities has been even further enhanced by its "Continental Shifts: Divisions and Solidarities" theme at the 2011 meetings. And insofar as this encourages the rethinking of old paradigms in light of the changing geography of the global political economy, I would like to suggest we start with the way old theories of imperialism and underdevelopment in particular may have occluded more than they clarified about how global capitalism has taken shape, and also how their lingering effects may still be occluding many of the key strategic questions that socialists ought to be addressing today.

The classical theory of inter-imperial rivalry - conceived in the pre-World War One era to understand the export of capital and the rush for colonies amid the emergence of 'finance capital' - increasingly got in the way of understanding the role and nature of the American empire in the making of global capitalism. As Sam Gindin and I have developed the argument over the better part of the past decade, ${ }^{1}$ the old capitalist empires of Europe and Japan were penetrated and incorporated by the US informal empire after World War Two. This involved a certain 'imperialism by invitation' - some called this their 'Canadianization' - whereby the linkages among the advanced capitalist states

\footnotetext{
${ }^{1}$ See our The Making of Global Capitalism, New York: Verso, forthcoming 2012, on which this talk is substantially based. 
became denser and stronger than the ties with their (increasingly ex-) colonies in the South. The American state underwrote the industrial reconstruction of Europe and Japan, and became the recipient of their burgeoning manufacturing exports. It also laid the grounds for US multinational corporations expansion and the creation of the Eurodollar markets, so that by the early 1960s twice as much US FDI went to Europe as to Latin America, reversing the historical pattern. Amid the twin pressures of the breakdown of the Bretton Woods system of fixed exchange rates and the domestic class contradictions to which Keynesian policies and near full employment gave rise by the 1970s, expectations of a decline of both the dollar and of US hegemony became widely heard, and this was seen as guaranteeing the reemergence of political rivalry among the advanced capitalist states. But this failed to appreciate the significance of the growing economic interpenetration and the dense networks of institutional collaboration among the advanced capitalist states. Despite the so-called 'varieties of capitalism' that were seen as differentiating these states, there was a common turn by the early 1980s to a more or less gradual embrace of neoliberalism alongside a further spread of American financial, corporate and legal practices.

The American empire's post-war relationship with the global south was very different. The global division of labour coming out of WWII was rigid and clear: manufacturing was largely concentrated in the former imperial countries and resource extraction in their dependencies. The breaking down of the old imperial order and the emergence of new nation states did not in itself overcome but rather continued to reproduce the old global division of labour through more informal means, punctuated by repeated coercive interventions against economic nationalist, let alone explicitly Communist, political forces in the 'third world'. It was in this context that the thesis of the development of underdevelopment caught on. A certain reluctant accommodation by the US in the 1950s to Import Substitution Industrialization (ISI) gave way by the 1960s to its promotion of export-oriented capitalist development, but this occurred just as a rising tide of economic nationalism as well as rising commodity prices was emanating from the global south. This culminated in the UN General Assembly's overwhelming vote in 1974 to adopt an Economic Charter which asserted the right of states to "nationalize, expropriate or transfer ownership of foreign property." Yet, as an internal US Treasury document noted in 1975, since developing state representatives were also coming down to Wall Street to either invest or borrow recycled petrodollars, and were anxious to display their 'reasonableness' as they did so, the bankers were already learning to 'discount the rhetoric'.

Long before the end of the $20^{\text {th }}$ century the thesis of the development of underdevelopment had come to look as threadbare as the old theory of inter-imperial rivalry. This was due to the integration, often through the crucible of economic crisis, of so many states in the global south into the circuits of global capitalist production as well as finance over the last quarter of the century. By 2000, manufacturing as a portion of 
GDP was actually higher in the developing countries (23 per cent) than in the developed ones (18 per cent). The shift to export-led manufacturing production involved not only a transformation in the international division of labour but also the reconfiguration of social relations in one country after another, as their capitalist classes became more and more linked to international capital accumulation, and the spatial and social effects of the restructuring of production gave rise to a massive expansion of the proletariat. Combined with the growing administrative and technological capacity of the MNCs to take advantage of local conditions like cheaper and abundant labour supplies, this opened the door to significant manufacturing taking place within a great many developing countries, even in such technologically-advanced sectors as electronics, transportation, and machinery. This did not mean, however, that global hierarchies did not persist, as many strategic activities (research and development, engineering, and capital intensive high valued-added production) were still highly concentrated in the advanced capitalist countries. And even at the end of the $20^{\text {th }}$ century, 90 per cent of all financial assets, 85 per cent of all FDI outflows and two-thirds of inflows, 65 per cent of world GDP, and almost 70 per cent of global exports of manufactured goods was still accounted for by the advanced capitalist countries. But this continued dominance increasingly reflected their active role and growing stake in the capitalist development of the global south.

As MNCs and international bankers picked and chose where to go, some regions, especially large parts of Africa, were left out, even as in other regions more and more states did become more and more integrated into the dynamics of global capitalism. And within each region the process was always uneven, according to the nature of the state and class alignments in individual countries and the way in which the integration was fostered (or occasionally blocked) by the actions of the advanced capitalist states. The recycling of petrodollars had left Latin American states more subject than ever to crises generated in the North American imperial heartland, as was dramatically revealed when they became the unintended casualty of the high interest rates generated by US Federal Reserve's domestic anti-inflation policy. The so-called 'Volcker shock' that spanned the Carter and Reagan administrations not only was the crucial background condition for policies that broke the back of trade unionism at home, it also turned out to have the same effect on economic nationalism abroad. The US Federal Reserve and Treasury developed a comprehensive strategy that radically expanded the superintendence of interbank repayment risk, while at the same time ensuring that the strict lending conditionality the IMF attached to its loans required long-term structural adjustment programs designed to protect and guarantee financial assets through the economic and political liberalization of each recipient state. Latin America's notorious 'lost decade' of the 1980s involved a 9 per cent fall in GDP per capita alongside unprecedented increases in class inequality. But part and parcel of this was the change that domestic capitalist classes were undergoing themselves. Ruling class families embraced the opportunities opened up by neoliberal globalization as they sent their sons off to the Harvard Business 
School, and as they shifted away from reliance on domestic markets and turned to foreign contracts, capital and outsourcing, while accepting the loss of the old tariff protections and price supports as the 'bitter medicine' necessary to bring their agricultural and manufacturing sectors into a 'competitive position.'

Similar trends were clearly visible in other former stalwarts of ISI such as India and Turkey where business groups came to see the system of internal controls and artificial monopolies as an obstacle to their own expansion. Hopes began to grow that other states might follow in the tracks of South Korea whose export-led industrialization became the beacon of capitalist developmental success, as measured by the growth of manufacturing products as a proportion of South Korea's exports from 18 per cent in 1962 to 77 percent by 1970 and 90 per cent by 1980. Although the preferences given to South Korea by the American state for geostrategic reasons had been key to this allowing it both currency undervaluation and asymmetric access to US markets - the socalled 'Korean model' was increasingly emulated through the 1970s by other states in East Asia like Malaysia, Thailand and Philippines, and by the end of the decade by the new Chinese Communist leadership. Meanwhile, the lending strategies of Western banks, which combined with the sclerosis of 'actually existing socialism' had already turned Poland, Yugoslavia and Hungary, among other Communist states, into sizable debtor states during the 1970s, presaged the grand opening to capital accumulation once Gorbachev's 'revolution from above' (naively emulating Western European social democratic 'mixed economies' just as they were themselves engaged in expanding capitalist markets) opened the doors to Eastern Europe's stampede to capitalism by the end of the 1980s. And even in those regions where the political relationship with the American empire became ever more fraught (as in the Middle East with Iran and Iraq) there was still nothing like an economic rupture. Expropriations of foreign capital largely became a thing of the past. Having already declined from a global total of 83 in 1975 to 17 in 1979, they fell to 5 in 1980, 4 in 1981, 1 in 1982, 3 in 1983, one each year from 1984 to 1986 - and zero for the rest of the decade.

The initiation by the US in 1977 of a bilateral investment treaty program was all about firmly establishing in international law "the principle that the expropriation of foreign investment was unlawful unless accompanied by prompt adequate and effective compensation." This program was carefully designed to establish codified state commitments to specific standards of investment protection, and binding 'depoliticized' quasi-juridical dispute resolutions procedures. This became the basis for BITs with ten developing states already strongly tied to the US, but it was only after the central elements of this model were incorporated in the Canada-US Free Trade Agreement that the US BIT program really took off. And by the time NAFTA was in place by mid-decade, no less than 27 more US BITs had been signed with other countries (10 more were signed by 2005). It was the guarantees they provided against expropriation of capital, twenty years after General Assembly's adoption of its Economic Charter of Economic Rights and 
Duties of States, which were now 'greasing the wheels' of global capitalism, along with the more than 700 regulatory changes states made between 1990 and 1997 that were favourable to foreign investment. It was hardly surprising in this context that US law firms, which tripled their number offices in Europe and Japan between 1985 and 1999, opened new offices in the rest of the world at an even greater rate.

This was part and parcel of a much broader concern with fashioning the political and legal frameworks through which such a diverse array of states could be integrated into international capital accumulation. This was most clearly articulated in the 1997 World Development Report during Joe Stiglitz's tenure as Chief Economist at the World Bank, which issued a call - much in tune with Tony Blair's articulation of the 'third way' at the time - for transcending 'the sterile debate of state and market'. This involved a certain social democratization of globalization rhetoric, especially by speaking in terms of 'state effectiveness' in developing the kind of public rules and institutions that 'allow markets to flourish'. What was being recognized here was that far from the globalization of production and finance 'disembedding' markets from society, it was the ways in which capitalist 'laws of value' were embodied in 'rules of law' that made possible the further proliferation and spatial expansion of markets. Yet globalization was all along intimately connected with legislative and administrative changes to deepen and extend market competition, including extensive treaties and coordination among states to this end. The more capital became internationalized, the more states became concerned to fashion regulatory regimes oriented to facilitating the rapid growth of international trade and foreign investment.

All this cannot properly be understood as merely an external imposition of 'structural adjustment' on the states of the global south. It was every bit as much the product of powerful domestic actors seeking to take advantage of access to international capital and foreign trade, even as this at the same time intensified the contradictions associated with becoming more and more exposed to the volatility of global finance, as was evidenced in the no less than 72 financial crises in the 1990s. In fact, just as the US Treasury, together with the Federal Reserve, was in the forefront of advancing the rules of law for allowing global financial markets to flourish, so did the constantly chaotic and intermittently crisis-prone nature of these markets increase the scope, and the demand, for global discretionary state intervention. The US Treasury explicitly took the view that its key role was one of 'failure containment' rather than 'failure prevention'. Larry Summers drew an analogy with jet aircraft:

Global financial markets let us go where we want more quickly, more comfortably and most of the time more safely than was possible before. But the crashes, when they occur, are that much more spectacular... We need systems that can handle failure because until the system is safe for 
failure, we will not be able to count on success (Financial Times March 11, 1998).

In April 1998, in the wake of the Asian financial crisis, the US Treasury convened a meeting in Washington, D.C. of the finance ministers and central bank governors of what would soon become the G20. The immediate outcome of this was the creation of three working groups of representatives from various states - supported by US Treasury staff - which produced reports on what needed to be done to strengthen the international financial system in terms of 'enhancing transparency and accountability', 'strengthening financial systems' and 'managing international financial crises'. It was taken for granted that all this would be modeled on Anglo-American 'best practice' in regulation and supervision, not least because so much of the world's financial regulatory expertise was concentrated in the US and UK. What was meant by the 'new international financial architecture' was a series of institutional reforms, primarily involving changes to the states and financial systems of 'emerging market' countries, which would allow investors to assess risks more adequately and help the IMF address crises more expeditiously. But by the time the Treasury's reports were ready, the failure of Long Term Capital Management and the near-death crisis it had already sparked on Wall Street in the late summer of 1998 had already shown that Anglo-American 'best practices' were hardly suited to preventing crises. What was especially notable about the 1997-1998 financial crises was the scale of the US Treasury's direct interventions, and their coordination with the other G7 states and financial institutions, that served to contain them.

Most significant for the continued extension of global capitalism was what developing states did not do in the wake of the Asian contagion with regard to restricting capital flows. With strong US as well as EU encouragement, the liberalization of capital markets continued into the $21^{\text {st }}$ century, so much so that 90 per cent of the almost two thousand changes states made to regulations governing foreign investment in the ten years after 1997 were favourable to it. This further facilitated foreign direct investment, so much so that it reached 32 per cent of global GDP by 2007 (from 6.5 per cent in 1980); and while only one quarter of this flow went to the global south, it was accompanied by a growth of local bond, securities and consumer credit markets that increasingly resembling those in advanced capitalist countries. Apart from strengthening the links between domestic and foreign capitalists, this also involved bringing local middle and even working classes into the financial system as never before. Financialization in the global south also facilitated the outward flow of capital, coming not only came from the foreign banks operating there, but also from local capitalists who were expanding their horizons beyond their home base. Of course, the largest capital outflows from the developing world took the form of purchases of US Treasuries. But this was not simply a costly transfer of wealth from the global south to the north; it was a necessary condition of successful export-oriented capitalist development, as central bank reserves served as an 
insurance policy against future runs on local currencies, as well as a means of maintaining exchange rates relative to the dollar.

It was now not only South Korea that had manufacturing goods account for over 90 per cent of its exports: so did Mexico, with Turkey ( 81 per cent), India (78 per cent) and Brazil (60 per cent) not far behind. Moreover, far from the shift of productive activity from the developed core leading to a fragmentation of production, it was part and parcel of a much greater global coordination of production through a broad range of subsidiaries, suppliers and distributors. Nowhere was this clearer than with the integration into global capitalism of China, which even before its accession to the WTO in 2001 had manufacturing goods account for almost 90 per cent of its exports. The crucial lesson the Chinese government drew from the Asian crisis was that in a world of such massive capital mobility, a run on the currency would overwhelm capital controls if the country's central bank was not also holding massive dollar reserves. And especially with China's admission to the WTO in 2001, it was positioned to secure the massive export surpluses that enabled these reserves to be built up. Before it was admitted to the WTO, China's total trade (exports and imports) as a share of GDP was, at 43 per cent, well below the average for low and middle-income countries; by 2007, its 68 per cent trade-to-GDP ratio was well above the average of those other countries. By this time, too, China's average tariffs on industrial products were under 9 per cent, compared with 27 per cent in Brazil, 31 per cent in Argentina, 32 per cent in India and 37 per cent in Indonesia. The surge of capital investment after China's entry to the WTO came from MNCs that wanted to use China as an export platform. But many were also interested in China's domestic market, with multinationals chomping at the bit to invest, not only in the retail trade but also in transportation and telecommunications as well as a variety of business services. That said, even China's rapid capitalist development did not take place at the expense of the American empire as much as reflect the spread and deepening of capitalist social relations on a global scale.

One measure of the American stake in the making of global capitalism was that total US trade (exports plus imports) equalled 30 per cent of GDP in 2007, whereas it had still been under 10 per cent in the 1960s. Despite all the anxiety on the one hand and schadenfreude on the other, about the declining productive capacity of American capital, US corporations were able to take special advantage of the open world they had been so central to creating. The measure of this success was not the proportion of global production that took place in the US (this had clearly fallen over time as a by-product of the successful promotion of capitalist social relations abroad), but rather the strategic importance of American capital in the global economy. The US accounted for between 60 and 75 per cent of all OECD research and development expenditures in such high tech sectors as aerospace and scientific instruments, and 45 to 50 per cent in electronics and pharmaceuticals. While US manufacturing job losses were indeed heavy after 2001 (especially in auto and electrical appliances as well as the long-suffering textile and 
apparel sector), the US was still producing more manufactured goods than all the BRICs (Brazil, Russia, India and China) combined. Rather than taking the US trade deficit as a measure of industrial decline, it is instructive to consider US exports and imports separately. The growth in the volume of US exports in the two decades up to 2007 - even as the trade deficit accumulated - averaged a very robust 6.6 per cent, leaving it only marginally behind Germany and China, the world's largest exporters; it was the relative expansion of US imports that was the source of the growing deficit.

The deficit, in other words, primarily came from increased US consumption, which grew faster than in other advanced capitalist countries. This was partly linked to the very high income growth and conspicuous consumption of the most well-off segments of the US population, but it was also due to much faster population growth than in Europe and Japan, the longer hours worked by much of the US population and, very significantly, their increased consumer debt. It was in good part US consumer spending that maintained effective global demand into the first years of $21^{\text {st }}$ century. This was supported by the international flow of funds into the US despite the size of the trade deficit. It was largely the failure to take sufficient account of the dominance and integration of American production and finance that led to the misreading of what US trade deficits might signal by way of undermining the value of the dollar and its place as the world currency. The increasingly integrated manufacturing networks of American MNCs on a global scale certainly accelerated the shift in US employment from manufacturing into lower-paid consumer and business services, but this reflected the strengthening rather than weakening of American capital, while the continued inflow of foreign capital to the US in spite of the trade deficits also confirmed the strength of the dollar. It was the balance of capital flows more than the balance of trade that now determined the dollar's value.

It is in this context that the crisis that began in 2007 needs to be placed. It was a crisis 'made in America' that had global ramifications but it was not the outcome of the declining profitability of manufacturing corporations or the size of the US trade deficit. By 2006, the US economy had experienced three years of over 3 per cent growth in real terms, with exports rising by over 8 per cent, and unemployment falling from 6 to 4.6 per cent. Annual productivity growth had continued to increase right through the first six years of the new millennium: its 2.8 per cent average rate of growth matched US levels during the postwar 'golden age'. Corporate profits were at a peak and corporate balance sheets were exceptionally strong. The American crisis that started in 2007 was not caused by either 'overaccumulation' or 'external imbalances' but rather by the volatility of capitalist finance. It was triggered in the seemingly mundane sector of mortgage credit, where finance mediated working class access to housing, and then quickly spread into the more rarefied world of interbank lending and corporate commercial paper markets. It was because US finance had become so integral to the functioning of $21^{\text {st }}$ century global capitalism that the ultimate impact of this crisis throughout the international economy 
was so profound. Securitized mortgage credit served to tie together high finance and low finance: it came to play an important role in the super-leveraging and integration of global financial markets, just as it had become a key element in consumer demand and credit.

Constrained in what they could get from their labour, US workers were drawn into the logic of asset inflation not only via the investment of their pension funds, but also via the one major asset they held (or could aspire to hold) in their own hands - their family homes. As wages stagnated and the income gap widened, growing segments of the home-owning working class sustained their consumption through taking out second mortgages on the bubble-inflated values of their homes. The rising demand for home ownership at lower income levels had been encouraged by government support for meeting housing needs through financial markets backed by mortgage tax deductions. Already well under way during the 1990s, the trend was given a great fillip not only by the Fed's low interest rates but also by the Bush administration's determination to expand the scope for 'entrepreneurs' in the business of selling home mortgages, although it was mainly long-established private mortgage companies that benefited from this. How common not just lax lending practices but in fact predatory lending became can be seen from the fact that between 2000 and 2007 in Florida alone 10,500 people were licensed as mortgage brokers who had criminal records (including over 4,000 who had previously been convicted of 'fraud, bank robbery, racketeering and extortion'). But no less responsible than those brokers who were essentially licensed loan sharks were the mainstream financial institutions for which the brokers were the middlemen, and which actually secured the loans for home purchases in areas previously 'redlined' by the banks. The whole edifice was connected to the American state itself via the old federal housing corporations, Fannie Mae and Freddie Mac, which although they had been privatized three decades earlier had remained government-sponsored enterprises (GSEs). Given the implicit guarantee the federal government gave to GSE securities, financial markets regarded them to be virtually as safe as Treasury bonds while yielding a higher return no small factor at a time when real interest rates on Treasuries were effectively negative.

The extent of the interpenetration of US and foreign financial markets was especially marked in the years leading up to the 2007 financial crisis. Yet, as foreign financial markets became intertwined with US financial markets, so were they subject to their smouldering contradictions. The way the crisis spread showed that predictions that it would lead to delinking from an American-led global capitalism were profoundly mistaken. If anything it sparked concerns that US domestic preoccupations amid the crisis might lead it to neglect the interests of foreign bourgeoisies that had come to rely on the American state. The extent to which capitalists abroad continued to look to the US to help them restructure their own states was seen when Obama visited India in November 2010, accompanied by the largest ever entourage of US businessmen on such a trip, and told an assembly of Mumbai capitalists: "We don't simply welcome your rise, we ardently 
support it. We want to invest in it" (Sunday Hindustan Times, 7 November 2010). The importance of this to Indian capitalists was made very clear by the co-founder of India's National Association of Software and Service Companies, who recalled that the US 'was the one who said to us... "Go for free trade and open markets." This was crucial to his industry's success in "pushing our government to open our markets for American imports, 100 percent foreign ownership of companies and tough copyright laws when it wasn't fashionable." Stressing the continuing importance of the US in overcoming 'the socialist/protectionists among India's bureaucrats', he emphasized that "We don't want America to lose self-confidence... there is nobody else to take that leadership. Do we want China as the world's moral leader? No. We desperately want America to succeed" (New York Times, 31 October 2010).

That said, the growing difficulties of implementing adequate measures for 'failure containment', let alone 'failure prevention' became very clear as the global economic crisis spread and persisted. Yet unlike the 1930s this has not been due to a breakdown of cooperation among capitalist states. Although the G20 was born out of the contradictions that produced the crisis at the end the 1990s, it had taken a decade of further global integration of finance and production, and another even more serious global financial crisis before it was given much prominence - beginning with the leaders of the world's twenty leading capitalist states being called to Washington by George Bush in the ominous autumn of 2008. This facilitated the coordination of a temporary global stimulus in 2009 which put a floor beneath the deepest economic collapse since the 1930s; but more significant was the long-term pledge made by the heads of states to keep globalization going. As the G20 Toronto Summit communiqué of June 2010 proclaimed: "While the global economic crisis led to the sharpest decline of trade in more than seventy years, G20 countries chose to keep markets open to the opportunities that trade and investment offer. It was the right choice." The leaders renewed their "commitment to refrain from raising barriers or imposing new barriers to investment or trade in goods and services... [and] minimize any negative impact on trade and investment of our domestic policy actions, including fiscal policy and action to support the financial sector." But capitalist solidarity itself could not resolve the crisis of a finance-led global economy, where the orthodoxy of insisting on austerity - both to ensure that states pay their bond holders and to maintain vigilance against inflation - reinforced the stagnationist tendencies of under-consumption that comes with diminished consumer credit available to sustain effective demand.

The severity and extent of the current crisis has once again exposed how far the world's states are enveloped in capitalism's irrationalities. Even when states stimulated their economies in 2009, they felt impelled at the same time to lay off public sector workers or cut back their pay, and to demand that bailed-out companies do the same. And while blaming volatile derivatives market for causing the crisis, states promoted derivative trading in carbon credits in the hope that a 'green capitalism' would provide a 
two-for-one remedy for the global climate and economic crises. In the context of such readily visible irrationalities, a strong case can be made that to really save jobs and the communities that depend on them in a way that converts production and distribution to conform with ecologically sustainable priorities, there needs to be a break with the logic of capitalist markets rather than the use of state institutions to reinforce them, beginning by finance into a public utility, and then proceeding to restructure its purpose and functioning as part of a system of democratic economic planning. This would itself require profound changes in class and state structures, and new international solidarities would need to be forged to see this through. The new working class struggles that have attended this crisis, from the strike wave by Chinese workers to the rapid growth of the New Trade Union Initiative in India to the mobilizations in defense of public sector unions in Wisconsin and Ohio are only a small foretaste of what would be needed to lay the foundation for this - not least through the development of new socialist political parties that would be oriented to a radical restructuring of states on all continents, so as to really make them substantively democratic in ways that capitalist states can never be. 